\title{
Penolakan Indonesia dalam Meratifikasi Konvensi UNESCO Tahun 2001 tentang Perlindungan Cagar Budaya Bawah Air
}

\author{
Rizky Widiasa \\ Universitas Indonesia
}

\begin{abstract}
The 2001 UNESCO Convention on the Protection of Underwater Cultural Heritage houses countries that have a vision and mission to protect underwater relics. By emphasizing the aspects of cooperation based on notification and reporting, this convention normatively measures the implementation of programs that depend on the capabilities of its member countries as a regime for archaeological relics preservation that sank on the seabed. Until now the Indonesian government has not ratified the convention and even tends to reject it. In fact, Indonesia as an archipelagic country has the responsibility to preserve the legacy of underwater cultural heritage in its sea area. This article analyzes the strategic decision of the Indonesian government to delay ratifying the 2001 UNESCO Convention on the Protection of Underwater Cultural Heritage. The theory of state participation in international organizations suggests that a convention requires commitment from the parties involved to solve global problems. Ratification is needed by the state to be bound by the convention to achieve national interests. In the end the decision not to join the convention was due to its impact which did not provide benefits for the state.
\end{abstract}

Keywords: state participation; international organizations; ratification

\begin{abstract}
Abstrak
Konvensi UNESCO tahun 2001 tentang Perlindungan Cagar Budaya Bawah Air mewadahi negaranegara yang memiliki visi dan misi untuk melindungi peninggalan bawah air. Dengan menekankan aspek kerja sama yang berbasis notification and reporting, konvensi ini secara normatif mengukur implementasi program yang bergantung pada kapabilitas negara-negara anggotanya sebagai rezim pelestarian peninggalan arkeologis yang tenggelam di dasar laut. Hingga saat ini pemerintah Indonesia tidak meratifikasi konvensi tersebut bahkan cenderung menolaknya. Padahal, Indonesia sebagai negara kepulauan memiliki tangggung jawab untuk melestarikan peninggalan cagar budaya bawah air di wilayah lautnya. Artikel ini menganalisis keputusan strategis pemerintah Indonesia yang menunda untuk meratifikasi Konvensi UNESCO tahun 2001 tentang Perlindungan Cagar Budaya Bawah Air. Teori partisipasi negara dalam organisasi internasional mengemukakan bahwa sebuah konvensi menuntut adanya komitmen dari pihak-pihak yang terlibat untuk menyelesaikan permasalahan global. Ratifikasi dibutuhkan oleh negara agar dapat terikat dengan konvensi tersebut untuk meraih kepentingan nasional. Pada akhirnya keputusan untuk tidak bergabung dengan konvensi tersebut dikarenakan dampaknya yang tidak memberikan manfaat bagi negara bahkan cenderung merugikan.
\end{abstract}

Kata-kata kunci: partisipasi negara; organisasi internasional; ratifikasi 


\section{Pendahuluan}

Indonesia menghadapi berbagai ancaman dan tantangan dalam mengelola potensi kekayaan cagar budaya bawah air yang bersifat fisik mekanis hingga biologis mekanis (Manders, 2012) dan aktivitas manusia (Ridwan, 2014). Definisi cagar budaya dalam UU Nomor 11 Tahun 2011 tentang Cagar Budaya adalah "warisan budaya berupa benda, bangunan, situs, dan kawasan di darat dan/atau di air dan memiliki nilai penting bagi peradaban manusia." Upaya perlindungan cagar budaya menjadi penting karena akhir-akhir ini marak terjadi perusakan dan pencurian ilegal benda-benda bersejarah tersebut. Diperlukan hukum dan regulasi yang optimal untuk mencegah potensi tersebut hilang begitu saja. Penyusunan regulasi dan penegakan hukum menjadi lebih sulit apabila lokasi benda atau kawasan cagar budaya itu terletak di dasar laut. Wilayah laut adalah wilayah yang batas geografisnya bias dan membutuhkan peran aktif dari dunia internasional untuk melindunginya. Perampasan relik sejarah di bawah laut telah terjadi sejak tahun 1970-an dan proses untuk menciptakan kerangka hukum mengenai hal ini berjalan sangat lambat (Batubara, 2014). Negara sebagai perangkat otoritas modern membutuhkan kerja sama dengan negara lain melalui instrumen konvensi dan perjanjian untuk mengatur tata tertib internasional (Keliat, 2005). Salah satu perjanjian internasional paling komprehensif yang membahas tentang perlindungan cagar budaya bawah air adalah "Konvensi UNESCO tahun 2001 tentang Perlindungan Cagar Budaya Bawah Air". Ketidakikutsertaan dalam konvensi ini perlu dianalisis mengingat Indonesia adalah negara maritim terbesar di dunia dan memiliki situs-situs cagar budaya bawah air yang tersebar di berbagai titik perairan nusantara.

Kaum liberal-institusionalis setidaknya sejak hampir tiga dekade lalu menjawab kritik kaum neo-realis bahwa institusi adalah instrumen penting dalam menciptakan perdamaian melalui regulasi, fasilitas decision-making, dan penyelesaian sengketa (Frieden, Lake, \& Schultz, 2009; Nye Jr, 2007)). Mereka berpendapat bahwa institusi dapat secara independen mempengaruhi perilaku suatu negara (Keohane \& Martin, 1995; Botcheva \& Martin, 2001). Dalam paradigma ini diakui bahwa rezim internasional adalah cara efektif untuk mengakomodasi persamaan kepentingan dari sejumlah aktor yang terlibat untuk menjawab tantangan masa depan yang tidak pasti (Axelrod \& Keohane, 1985). Institusi sebagai kepanjangan tangan negara kapital melalui rezim yang dibentuk dianggap akan selalu menjadi otoritas yang mengikat potensi negara-negara berkembang. Hal inilah yang mendasari pemikiran kaum realis bahwa tatanan internasional yang bersifat anarki selalu menghendaki satu atau sekian aktor akan mendapat bagian lebih dibanding yang lain dalam suatu rezim kerja sama. Karena sejatinya negara (sebagai aktor rasional) hanya akan memikirkan nasibnya sendiri (Waltz, 1979; Grieco, 1988). Akibatnya institusi memiliki tendensi untuk dikuasai oleh kepentingan negara besar dan penghitungan urgensi terhadap suatu isu akan bergantung kepada negara-negara pemodal sebagai refleksi dari power yang mereka miliki (Mearsheimer, 1994; Mintz \& DeRouen, 2010). Sehingga dapat disimpulkan bahwa institusi mungkin saja dapat menjadi alat ofensif maupun defensif terhadap negara rival (Snidal, 1991).

Perlindungan cagar budaya bawah air nasional dalam perspektif norma internasional merupakan topik yang masih minim mendapat perhatian. Banyak kajian-kajian komprehensif pada penelitian sebelumnya lebih menekankan aspek hukum internasional secara geopolitik (Campbell, 2005; Laksmana, 2011; Tismananda, 2016) sedangkan dalam perjanjian kerja sama internasional, persepsi ditentukan oleh intersubyektifitas cara pandang tiap aktor dalam melihat norma 
dan nilai yang dibentuk oleh setiap subyek yang terlibat. Norma dan nilai itu terkonvergensi menjadi sebuah sistem yang mengikat pada sistem yang kooperatif. Dengan melihat konsekuensi dari konvensi sebagai ancaman, secara konstruktif artikel ini bermaksud untuk menggunakan struktur identitas dan kepentingan nasional sebagai justifikasi untuk menjelaskan perilaku Indonesia dalam berupaya menjaga kedaulatan warisan sejarahnya.

\section{Kerangka teori}

Pandangan realis melihat institusi sebagai instrumen untuk merefleksikan power dari negara kapital dan memiliki tendensi untuk dikuasai negara kapital. Dengan begitu apabila Indonesia memutuskan untuk bergabung dalam konvensi perlindungan cagar budaya maritim, kemungkinan malah akan menjadi kerugian besar bagi negara. Menurut Sitaraman (2009), perjanjian atau treaties yang melibatkan hubungan multilateral adalah tentang ratifikasi. Tujuan utama dari ratifikasi adalah untuk memastikan otoritas domestik mengevaluasi kesepakatan perjanjian. Bagi negara demokrasi, proses ratifikasi perjanjian multilateral melibatkan parlemen, atau badan legislatif lainnya yang mewakili kehendak rakyat. Maka dari itu tidak jarang bergabungnya suatu negara dalam perjanjian khusus membutuhkan opini publik yang kuat.

Perilaku negara dalam perjanjian multilateral secara parsial dapat dijelaskan dengan menganalisis hubungan kausal antara struktur politik domestik, norma sosial internal, dan isu yang dibahas dalam suatu rezim internasional. Perjanjian multilateral tidak hanya tentang berbagai isu yang beredar sesuai dengan perkembangan zaman. Melainkan juga mengenai penetrasinya terhadap kebijakan nasional yang sejatinya adalah hak dan kedaulatan milik sebuah negara bangsa. Kebanyakan studi mengenai dampak yang dihasilkan rezim berbasis perjanjian ini fokus pada kekuatan rezim dan rancang bangun rezim untuk memahami mengapa perjanjian kadang tidak berpengaruh terhadap perilaku negara dalam memenuhi kewajibannya. Chayes dan Chayes (1995) berargumen bahwa kerja sama internasional haruslah mempunyai mekanisme khusus yang memaksa negara anggota untuk memenuhi kewajibannya. Apabila ada anggota yang lalai dapat diberikan sanksi. Namun apabila itu yang terjadi, maka jika dilihat dari sudut pandang realisme dapat dipastikan negara akan lebih condong untuk menolak berpartisipasi dalam kerja sama intternasional. Karena dalam anarki motivasi yang dimiliki oleh setiap aktor eksternal adalah untuk memenuhi kebutuhannya sendiri.

Dapat disimpulkan bahwa negara akan condong mengambil langkah unilateral. Hal ini juga menjadi semacam premis yang tidak sepenuhnya sepakat bahwa institusi internasional seolah netral dari motif politik apapun. Padahal, realitas yang ada pada (kebanyakan) perjanjian internasional adalah melekatnya suatu rezim dengan norma atau paham politik tertentu. Maka dari itu mekanisme sanksi dari sebuah rezim dan rancang bangunnya menjadi dasar fondasi bagi suatu negara untuk ikut berpartisipasi atau menolak bekerja sama. Di samping itu, biaya politik yang harus dibayar juga menentukan apakah negara menganggap bergabungnya ke suatu perjanjian dapat menghasilkan keuntungan baginya. Ketika suatu negara bergabung, maka dapat diasumsikan bahwa perjanjian itu dapat mengakomodir kepentingan tertentu. Selain itu alasan negara bergabung dengan satu perjanjian namun menolak perjanjian lain sangat mungkin disebabkan oleh tekanan domestik maupun internasional. 


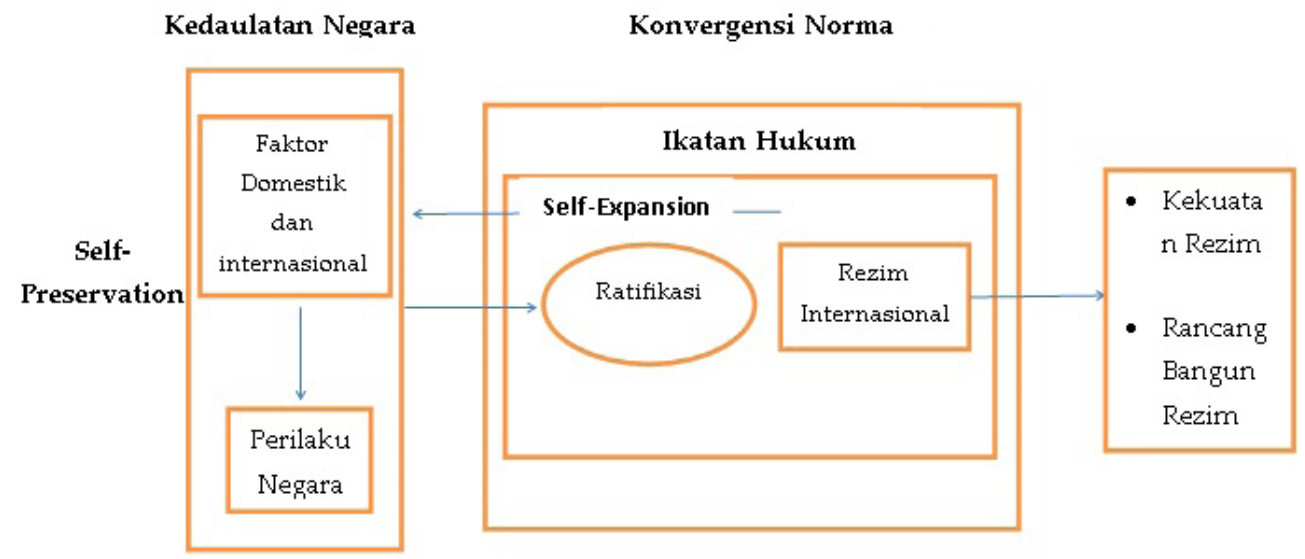

\section{Gambar 1. Skema Penolakan Indonesia dalam Rezim Perlindungan Cagar Budaya Bawah Air}

Ada dua unsur yang melegitimasi eksistensi sebagai wadah bagi negaranegara yang norma terkait isu cagar budaya bawah airnya telah tenkorvergensi. Unsur yang pertama adalah rancang bangun rezim. Rancang bangun atau desain sebuah rezim erat kaitannya dengan fondasi bagaimana suatu rezim terbentuk. Dalam rancang bangun ini juga akan dijelaskan bagaimana konvergensi norma dapat menjadi fondasi bagi hukum perlindungan cagar budaya bawah air dengan cara menentukan definisi dari cagar budaya bawah air itu sendiri hingga aturan menyangkut wilayah yurisdiksi yang dapat dijadikan panduan bagi negara untuk mengelolanya. Tidak lupa pula dijelaskan struktur dari konvensi sebagai bagian dari rancang bangun rezim agar dapat secara efektif berfungsi sebagai wadah dan mediator bagi negara-negara yang bersengketa. Unsur berikutnya adalah kekuatan rezim. Kekuatan ini digunakan untuk melihat sejauh mana rezim atau institusi internasional dapat menekan negara-negara lain (baik partisipan maupun non partisipan) untuk tunduk pada peraturan yang telah dibuat. Sebagai institusi yang menekankan ilmu pengetahuan, pendidikan, dan budaya tentu pengaplikasian kekuatan rezim tidak selalu bisa diidentikan dengan kekuatan militer semata.

Selanjutnya tindakan negara dipengaruhi oleh faktor-faktor domestik dan internasional. Faktor-faktor itu meliputi kebijakan politik dalam negeri yang dipengaruhi keputusan eksekutif maupun legislatif, hingga opini publik. Kebijakan politik domestik secara umum adalah kunci dalam memahami alasan beberapa negara bergabung dengan perjanjian/kesepakatan internasional (rezim internasional) dan beberapa diantaranya tidak. Selain domestik faktor internasional itu dapat muncul karena adanya kemungkinan perbedaan prinsip dengan sebuah rezim yang mengakibatkan negara tidak dapat memenuhi kepentingan nasionalnya. Perjanjian internasional beroperasi berdasarkan kesepakatan yang ditandai dengan tanda tangan perjanjian, dan ratifikasi. Resminya, partisipasi negara akan ditandai oleh ratifikasi sebagai langkah awal dalam internalisasi norma. Partisipasi negara-negara dalam rezim internasional sangat bergantung pada konvergensi norma. Apabila ratifikasi tidak dilakukan maka kerjasama internasional yang bersifat multilateral tidak akan berjalan sebagaimana mestinya. Sederhananya bergabung atau menolaknya negara terhadap sebuah kerjasama multilateral dapat dijelaskan sebagai berfungsinya struktur politik domestik secara 
keseluruhan sesuai dengan perjanjian yang sudah disepakati. Faktor domestik inilah yang menjadi indikator pertama sebelum diturunkan menjadi perilaku negara dalam bergabung atau menolak perjanjian multilateral. Kedua hal tersebut (faktor domestik dan perilaku negara) merupakan indikator yang menunjukan bahwa sebuah negara berdaulat untuk menentukan arah kebijakan yang dianggap mampu menyelesaikan berbagai problema.

Prinsip kedaulatan yang akan digunakan untuk menganalisa kepentingan nasional Indonesia berbasis pada implikasi penerapan hukum terhadap berbagai situasi termasuk aspek geopolitik. Prinsip ini bersifat perspektif dan dalam sudut pandang konstruktivisme, kedaulatan (seperti halnya anarki) merupakan sebuah institusi. Keduanya (kedaulatan dan anarki) timbul dimana ada pemahaman intersubyektif dan ekspektasi antar aktor (Wendt, 1992: 412). Argumen utama mengapa kedaulatan hukum menjadi bagian penting dari partisipasi negara dalam kerja sama internasional adalah adanya legitimasi bagi institusi untuk menerapkan power-nya di suatu teritori.

Pandangan realis melihat institusi sebagai instrumen untuk merefleksikan power dari negara kapital dan memiliki tendensi untuk dikuasai negara kapital. Dengan begitu apabila Indonesia memutuskan untuk bergabung dalam konvensi perlindungan cagar budaya maritim, kemungkinan malah akan menjadi kerugian besar bagi negara. Penolakan pemerintah Indonesia tidak bisa hanya dijelaskan dari ranah identitas historis semata yang terutama berpendapat mengenai distribusi knowledge dipahami oleh pihak yang secara intersubjektif menciptakan pemahamannya dengan entitas lain. Melainkan dibutuhkan suatu pemahaman sosial mengenai perilaku mengapa negara memutuskan untuk berpartisipasi atau menentang sebuah kerja sama internasional.

Penolakan suatu negara untuk bergabung dengan sebuah perjanjian multilateral biasanya dapat dijelaskan sebagai akibat dari dinamika yang terjadi pada struktur politik domestik. Dalam kasus penolakan Indonesia terhadap ratifikasi perjanjian perlindungan cagar budaya bawah air internasional, ada tiga faktor utama yang berkaitan dengan aspek politik domestik tersebut. Faktorfaktor itu adalah adanya tumpang tindih regulasi domestik, perbedaan prinsip, dan persoalan kedaulatan. Dua dari tiga faktor ini menunjukan bagaimana faktor domestik memiliki peran terbesar dalam pengambilan keputusan negara untuk terikat dengan sebuah perjanjian intenasional. Sedangkan faktor yang ketiga lebih terkait konsekuensi dari kedua faktor sebelumnya. Hal itu bukan berarti pemerintah Indonesia menolak norma hingga wacana yang menjadi menu utama dari rezim yang bersangkutan. Indonesia saat ini tergolong aktif dalam beragam aktifitas yang ditujukan bagi kepentingan pelestarian peninggalan bawah laut bersama UNESCO, menunjukan bahwa pemerintah masih terlibat dalam berbagai kegiatan prosedural terbatas.

\section{Tumpang Tindih Regulasi Domestik}

Pengelolaan cagar budaya bawah air di Indonesia masih mengalami tumpang tindih antara penggunaan untuk tujuan komersil atau konservasi. Sejak berlakunya UU Nomor 11 Tahun 2010 Tentang Cagar Budaya, kapal-kapal bersejarah dari berbagai era yang tenggelam di perairan Indonesia dimasukan kedalam kategori cagar budaya bawah air sesuai dengan ketentuan yang berlaku. Padahal sebelumnya pemerintah telah mengeluarkan Kepres untuk membentuk Panitia Nasional Pengangkatan dan Pemanfaatan Benda Muatan hasil Kapal Tenggelam (KEPPRES PP-BMKT). Kepres ini awalnya memuat berbagai aturan 
mengenai pemanfaatan benda muatan kapal tenggelam untuk tujuan komersial, namun seiring berjalannya waktu, Kepres ini menyesuaikan dengan kebutuhan zaman bahkan sempat terkena moratorium karena berbagai pertimbangan agar tidak memberikan izin untuk melakukan survey di berbagai lokasi kapal tenggelam. Indonesia sebenarnya telah memiliki instrumen-instrumen hukum yang tepat dalam isu ini. Hanya saja terdapat bias kewenangan antara instrumen satu dengan lainnya.

Sebagai gambaran umum, data dari Direktorat Cagar Budaya dan Permuseuman mencatat bahwa setidaknya dua kali pemerintah kecolongan dalam dua kasus besar pengangkatan muatan berharga dari kapal karam era kolonialisme banga Eropa sejak periode abad-14 hingga abad-18 yang tenggelam di perairan nusantara. Yang pertama adalah kasus pengangkatan ilegal kargo kapal Geldermalsen (Nanking Cargo) di perairan Riau milik Asosiasi Dagang Hindia Timur(VOC) pada pertengahan periode 1980-an dengan muatan berupa 126 batang emas dan 160.000 keramik kuno era Dinasti Qing. Kasus besar selanjutnya adalah pengangkatan kapal karam Tek Sing yang tenggelam di perairan Bangka-Belitung pada tahun 1822. Kapal Tek Sing ini adalah kapal dengan muatan keramik kuno paling masif yang pernah ditemukan. Terdapat muatan sekitar 360.000 keramik kuno berharga dalam kondisi sangat baik (Museum Nasional Indonesia, n.d). Kasus Geldermalsen, menaikkan pamor Michael Hatcher sang penemu muatan tersebut dan menjualnya melalui balai lelang Christie's di Amsterdam dengan nilai lebih dari US\$ 17 juta (BBC, 2008). Tidak berapa lama setelah mendengar kabar itu, pemerintah melakukan kerja sama dengan PT. Muara Wisesa Samudera yang secara tidak langsung dipimpin oleh Tommy Soeharto (anak dari Presiden Soeharto) untuk melakukan pencarian serupa dengan yang dilakukan oleh Hatcher (Widiati, 2018). Agar pencarian tidak terkesan serampangan, Presiden Soeharto kemudian membentuk Panitia Nasional Pengangkatan dan Pemanfaatan Benda Berharga Asal Muatan Kapal Tenggelam (PANNAS PPBMKT). Pembentukan PANNAS PP-BMKT ini termaktub dalam Surat Keputusan Presiden Nomor 43 Tahun 1989. PANNAS PP-BMKT ini memiliki tanggung jawab dan berkedudukan langsung di bawah Presiden Republik Indonesia (Pasal 2 Ayat 2), sekaligus berwenang mengeluarkan izin pengangkatan dan pemanfaatan yang permohonannya diajukan pihak lain (Pasal 3 poin b). Melalui ketentuan ini PT Muara Wisesa melakukan pengangkatan terhadap muatan kapal kuno yang tenggelam di perairan Nusantara. Saat itu pengangkatan muatan kapal kuno merupakan sesuatu yang baru bagi Indonesia karena dibutuhkan biaya yang sangat besar untuk melakukannya.

Beberapa tahun setelah Panitia Nasional menjalankan tugasnya dalam 'berburu harta karun', tepatnya pada tahun 1992 pemerintah menerbitkan UU Nomor 5 Tahun 1992 tentang Cagar Budaya. Undang-Undang ini hadir untuk menggantikan regulasi peninggalan benda dan bangunan bersejarah monumenten ordonnantie yang telah berlaku sejak tahun 1931 dan dibuat oleh pemerintah kolonial Belanda. UU Nomor 5 Tahun 1992 ini menggunakan formulasi yang hampir serupa dengan regulasi zaman kolonial yang ditujukan untuk melindungi dan melestarikan peninggalan bersejarah yang merupakan peninggalan manusia sekaligus hasil bentukan alam (Tanudirjo, 2007). Dalam Pasal 1(a) UU Nomor 5 Tahun 1992 disebutkan bahwa benda cagar budaya adalah "benda buatan manusia (bergerak atau tidak bergerak) berupa kesatuan atau kelompok, atau bagian-bagian atau sisa-sisanya yang berumur sekurang-kurangnya 50 tahun". Lalu dalam Pasal 2 tertulis "situs adalah lokasi yang mengandung atau diduga mengandung benda cagar budaya termasuk lingkungannya yang diperuntukan 
bagi pengamanannya." Dengan demikian pada periode ini Indonesia memiliki dua regulasi yang mengatur tentang peninggalan yang terletak di dasar laut yaitu Keppres Nomor 43 Tahun 1989 dan UU Nomor 5 Tahun 1992.

Berbagai dinamika politik di Indonesia turut mempengaruhi kebijakankebijakan yang berkaitan dengan Benda Muatan Kapal Tenggelam. Pada tahun 2000, dua tahun setelah reformasi dan tumbangnya Orde Baru (Orba), pemerintah mulai fokus untuk membenahi sisi maritim. Saat masa Orba segala hal yang berkaitan dengan kelautan merupakan kewenangan Kementerian Koordinator Bidang Politik, Hukum, dan Keamanan. Setelah era reformasi, Presiden Republik Indonesia saat itu Abdurahman Wahid membentuk Kementerian Eksplorasi Laut dan Perikanan. Mengenai Panitia Nasional juga terdapat beberapa perubahan signifikan terhadap regulasi yang ada. Presiden kemudian menerbitkan Keppres Nomor 107 Tahun 2000 Tentang Panitia Nasional Pengangkatan dan Pemanfaatan Benda Berharga Asal Muatan Kapal Karam. Keppres Nomor 107 ini adalah pembaharuan terhadap Keppres Nomor 43 Tahun 1989 yang tidak berlaku lagi sejak Keppress Nomor 107 diterbitkan. Perkembangan regulasi yang mengatur tentang Panitia Nasional tidak berhenti sampai disitu. Pada 2007 pemerintah Indonesia kemudian menerbitkan surat Keppres Nomor 19 Tahun 2007 menggantikan Keppres sebelumnya. Keppres Nomor 19 ini adalah regulasi paripurna yang mengatur tentang Panitia Nasional PP-BMKT. Jika dibandingkan terdapat beberapa poin krusial yang menjadi letak perbedaan antara KEPPRES yang satu dengan lainnya. Keppres Nomor 19 Tahun 2007 dianggap yang paling lengkap mengatur wewenang bagi Panitia Nasional untuk melaksanakan tugas dan fungsinya dalam pengangkatan dan pemanfaatan benda muatan kapal tenggelam.

Perbandingan pada ketiganya terletak antara struktur kepemimpinan dan pengenaan biaya yang disesuaikan dengan departemen yang bertanggung jawab terhadap peraturan tersebut. Pada Keppres Nomor 107 ditekankan bahwa BMKT juga termasuk dengan kapal-kapal Jepang dan China yang tenggelam di perairan Indonesia. Lebih lanjut lagi pada Keppres Nomor 107 dan Keppres Nomor 19 disebutkan bahwa BMKT adalah berasal dari kapal-kapal yang tenggelam yang berada di perairan Indonesia, ZEE, dan Landas Kontinen nasional. Ini merupakan penambahan wilayah yurisdiksi bagi dua Keppres ini mengingat Keppres Nomor 43 tidak membahas mengenai wilayah lokasi BMKT secara spesifik. Pada Keppres Nomor 107 juga menggunakan kriteria usia kapal tenggelam yang minimal 50 tahun sesuai dengan kriteria minimum usia dari benda cagar budaya.

Premis ini menunjukkan bahwa antara UU Nomor 5 Tahun 1992 dengan PANNAS BMKT dapat berjalan beriringan meskipun terdapat perbedaan prioritas antara pelestarian dengan komersialisasi. Antara keduanyajuga memiliki kesamaan dalam struktur kepemimpinan dimana Menteri Pendidikan dan Kebudayaan menjabat sebagai wakil Panitia Nasional pada ketiga Keppres tersebut. Keppres Nomor 19 Tahun 2007 kemudian mengalami revisi dan diperbaharui melalui Keppres Nomor 12 Tahun 2009. Perubahan itu terutama terletak pada Pasal 2 dan Pasal 4 yang memberikan definisi lebih rinci mengenai benda muatan kapal tenggelam. Dengan berlakunya Keppres 2007 (kemudian hasil revisinya pada 2009) menjadikan Keppres sebelumnya menjadi tidak berlaku. Sejauh ini antara UU Nomor 5 Tahun 1992 dengan Keppres PANNAS BMKT tidak terjadi benturan yang signifikan meskipun keduanya memiliki arah prioritas yang berbeda.

Dalam undang-undang cagar budaya yang baru (UU Nomor 11 Tahun 2010 Tentang Cagar Budaya), konservasi dan pelestarian merupakan prioritas 
bagi cagar budaya yang berada di darat dan air. Ini menutup kemungkinan bagi benda-benda muatan kapal tenggelam untuk dilelang dan dijual kepada pihak ketiga. Dengan begitu sejak adanya UU Nomor 11 ini benda-benda peninggalan bawah air untuk digunakan bagi kepentingan ekonomi statusnya menjadi dilarang. Perbedaan mendasar antara UU Nomor 5 Tahun 1992 dengan UU Nomor 11 Tahun 2010 adalah segala aktifitas yang ditujukan bagi benda/situs/ kawasan cagar budaya harus melalui penelitian dan standar operasional yang berlaku secara ilmu arkeologis. Ini berbeda dengan ketentuan yang berlaku dalam Keppres BMKT yang mengeluarkan izin survey bagi pihak lain melalui jalur nonpenelitian. Selain itu UU Nomor 11 ini juga melarang benda cagar budaya apapun untuk dibawa ke luar negeri kecuali untuk kepentingan pameran, penelitian, dan promosi. Sedangkan dalam ketentuan PANNAS BMKT membolehkan cagar budaya untuk dibawa keluar negeri untuk lelang. Dengan adanya dua regulasi yang berbeda menjadikan pemerintah memiliki dua alternatif arah pemanfaatan cagar bawah air. Itu menyebabkan sering ada miskoordinasi dan ketidak jelasan dalam pelaksanaan perlindungan peninggalan-peninggalan bawah air.

Karena arah prioritas yang belum jelas (disebabkan adanya dua regulasi yang bertolak belakang) maka asumsinya terhambat pula perencanaan yang berkenaan dengan alokasi anggaran bagi berbagai kebijakan pemerintah dalam isu peninggalan bawah air. Apabila Indonesia memutuskan untuk bergabung dengan rezim perlindungan cagar budaya bawah air, maka Indonesia harus mempunyai bargaining power dengan memakan cost besar. Besarnya biaya itu dapat dialokasikan untuk menciptakan berbagai teknologi demi kepentingan eksplorasi, pemanfaatan serta konservasi. Jika Indonesia telah maju dalam aspek-aspek tersebut maka itu dapat dimanfaatkan untuk mencegah negara ini didikte oleh ketentuan-ketentuan rezim yang dapat merugikan kepentingan nasional. Posisi tawar yang tinggi itu adalah hal yang sulit diwujudkan dalam waktu dekat ini mengingat kompleksitas regulasi yang sudah disebutkan tadi. Apalagi pemerintah juga memiliki berbagai masalah dari isu-isu lain yang berkembang di era kontemporer ini.

\section{Perbedaan Prinsip}

Adanya perbedaan prinsip dapat dilihat dari tiga unsur utama yakni masa periode waktu suatu peninggalan bawah air tenggelam, persoalan zonasi, dan klaim terhadap negara asal benda cagar itu memiliki akar. Dalam aturan konvensi yang diterjemahkan secara bebas menyebutkan bahwa cagar budaya bawah air adalah segala jejak eksistensi manusia yang memiliki karakter budaya, historis, maupun arkeologis yang telah tenggelam sebagian atau seutuhnya setidaknya selama 100 tahun (Pasal 1). Sedangkan definisi cagar budaya bawah air menurut UU Nomor 11 Tahun 2010 setidaknya memiliki kriteria yang kurang lebih sama secara definitif meskipun dapat diperdebatkan. Hanya saja periode tenggelam menjadi hal yang cukup krusial karena perbedaannya sangat signifikan. UU Nomor 11 Tahun 2010 menekankan bahwa benda, bangunan, atau struktur dapat diusulkan sebagai benda cagar budaya, bangunan cagar budaya, atau struktur cagar budaya apabila memenuhi kriteria salah satunya berusia 50 tahun atau lebih (poin a); dan mewakili masa gaya paling singkat berusia 50 tahun (poin B, Pasal 5 UU Nomor 11 Tahun 2010). Menurut Widiati (2018), penentuan masa usia struktur cagar budaya ditentukan minimal 50 tahun dikarenakan Indonesia adalah negara tropis, sehingga secara kimiawi dikhawatirkan benda-benda cagar memiliki resiko kemungkinan lebih cepat rusak. Menurut Widiati (2018), setiap negara di zona berbeda tidak bisa disamakan kriteria usia cagar budayanya karena hal tersebut 
dipengaruhi oleh beragam faktor seperti cuaca, iklim dan faktor-faktor lain yang dapat mempengaruhi kondisi suatu situs di bawah air.

Minimnya data publikasi dari UNESCO dan data akademis dari sumber lain mengenai kriteria usia cagar minimal 100 tahun menjadi hambatan dari analisis mengapa rezim konvensi menggunakan standar periode waktu tersebut. Penentuan periode kriteria benda cagar bawah air ditentukan oleh UNESCO diadahului oleh berbagai pertimbangan. Pembentukan rezim perlindungan cagar budaya bawah air dibuat berdasarkan draf naskah Asosiasi Hukum Internasional (ILA) dan International Council of Monuments and Sites (ICOMOS). Fungsinya sebagai instrumen hukum yang bertanggung jawab mengikat negara-negara dalam kerangka supra-nasional dalam perlindungan hukum bagi peninggalan bawah air. Selain kepada urgensi isu eksploitasi, dibentuknya rezim ini juga dikarenakan ILA dan ICOMOS adalah organisasi swasta dan tidak bergerak dalam level pemerintahan. Maka dari itu pembentukan rezim berdasarkan pertimbangan antara keduanya (ILA dan ICOMOS) dibentuklah konvensi perlindungan cagar budaya bawah air untuk mengikat negara-negara partisipannya dalam sebuah rezim (ICOMOS, 1996).

Penulis mencoba melakukan analisis dan menemukan kemungkinan bahwa penentuan usia dari suatu peninggalan bawah air dapat juga dipengaruhi elemen-elemen sektoral yang sifatnya prinsipil. Dalam UU Nomor 11 Tahun 2010 dicantumkan bahwa usia cagar budaya adalah 50 tahun. Selain karena faktor iklim dan kondisi laut, nampaknya kriteria usia tersebut dapat digunakan untuk memaksimalkan perolehan otoritas negara terhadap benda-benda cagar bawah air yang berada di perairan Indonesia. Sebagai contoh, apabila ada sebuah kapal yang tenggelam di wilayah perairan Indonesia selama 50 tahun, maka pemerintah dapat segera menentukan kebijakan yang tepat bagi pengelolaan kapal yang bersangkutan berikut muatannya. Apabila pemerintah Indonesia bertolak dari aturan konvensi yang menetapkan usia cagar adalah 100 tahun, maka pemerintah tidak dapat menjustifikasi sebuah benda muatan kapal tenggelam sebagai sebuah relik yang penting. Hal ini penting khususnya ditujukan bagi kepentingan ekonomi. Jika regulasi nasional yang digunakan, maka hanya dalam waktu 50 tahun pemerintah Indonesia dapat mengklaim bahwa sebuah situs, kawasan, hingga benda cagar budaya bawah air sebagai objek yang bernilai sejarah. Dengan adanya klaim bahwa sebuah objek dianggap bersejarah, maka objek tersebut dapat dikemas menjadi sesuatu yang dapat memiliki nilai tinggi bagi berbagai kepentingan nasional. Hal itu memiliki dampak positif untuk meningkatkan pendapatan dan citra positif negara di dunia internasional melalui turisme dan pameran internasional.

Hal yang sebaliknya dianggap tidak akan terjadi jika ketentuan 100 tahun menjadi acuan bagi pemanfaatan cagar budaya bawah air. Selain berpotensi mengalami adanya kerusakan disebabkan kondisi bawah laut yang tidak menentu, jika ketentuan 100 tahun menjadi acuan maka pemerintah tidak dapat memaksimalkan potensi-potensi seperti yang sudah disebutkan sebelumnya jika usia cagar budaya bawah air berusia 50 tahun. Memang, Indonesia memiliki banyak sekali peninggalan bawah air dari berbagai periode waktu dari abad ke II masehi hingga Perang Pasifik (Museum Nasional Indonesia, 2018), hanya saja tidak semua peninggalan itu merupakan barang yang setidaknya dianggap berharga dari segi ekonomi. Hal ini merujuk pada pengangkatan muatan kapal kuno oleh Panitia Nasional sekitar periode awal 1990-an. Panitia saat itu mengangkat sekitar 35.000 keramik China kuno dari abad ke-6 Masehi dengan kondisi sangat baik. 
Permasalahannya adalah pemerintah kesulitan mencari pembeli atau investor sehingga keramik-keramik tersebut hingga kini hanya tersimpan di gudang Panitia Nasional di Cileungsi (Widiati, 2018). Setelah dikaji lebih jauh, dibandingkan dengan muatan Geldermalsen dari abad 17 Masehi yang nilainya mencapai 17 juta dollar AS, muatan kapal China yang ditemukan Panitia Nasional memiliki usia yang jauh lebih tua. Keramik-keramik tersebut memiliki nilai sejarah yang sangat tinggi namun minim nilai ekonomi. Penentuan usia cagar budaya yang 'hanya' 50 tahun dapat juga dijadikan alasan agar pemerintah tidak kembali kecolongan apabila dalam melakukan berbagai survey dan ekplorasi, pemerintah mungkin kembali menemukan kapal karam dengan muatan benda-benda berharga.

Faktor permasalahan kriteria usia cagar budaya bawah air juga sedikit banyak mempengaruhi faktor berikutnya terkait klaim kepemilikan negara atas peninggalan bawah air di wilayah yang bersangkutan. Berdasarkan wawancara yang dilakukan dengan Widiati, salah satu kekhawatiran pemerintah dalam berpartisipasi dan meratifikasi konvensi UNESCO tentang Perlindungan Cagar Budaya Bawah Air adalah bahwa negara lain dapat melakukan klaim terhadap peninggalan bawah air yang merujuk pada identitas negara tersebut. Jika argumen pemerintah ini tepat sasaran maka tentu akan menjadi kerugian besar bagi Indonesia. Kerugian besar itu mengingat sebagian besar peninggalan bawah air Indonesia adalah berasal (atau bahkan pengaruh) dari bangsa asing yang dibawa ke nusantara melalui laut. Dalam sudut pandang perspektif pemerintah, kekhawatiran timbul jika pada akhirnya rezim dan dunia internasional memaksa Indonesia dipaksa untuk mengembalikan relik yang erat kaitannya dengan suatu bangsa kepada negara. Maka Indonesia dipastikan tidak akan memiliki peninggalan bawah air yang tersisa bagi negara Indonesia (Widiati, 2018).

Dalam ketentuan yang berlaku di konvensi, Rezim Perlindungan Cagar Budaya Bawah Air tidak bermaksud untuk bertindak sebagai arbitrer dalam urusan klaim mengenai kepemilikan cagar (Information Kit, UN Convention on The Protection of Underwater Cultural Heritage). Konvensi 2001 juga tidak ada ketentuan yang melindungi sebuah cagar budaya dapat diklaim oleh negara yang terkait dengan identitas suatu cagar budaya bawah air. Hanya saja kekhawatiran pemerintah itu secara realis dapat dipahami sebagai sebuah bentuk rasionalitas dalam memenuhi kepentingan nasional suatu negara yang wilayah lautnya terdapat peninggalan bawah air.

Persoalan prinsip berikutnya yang membedakan antara prioritas kepentingan Indonesia dengan rezim perlindungan cagar budaya bawah air internasional adalah perbedaan prinsip yang terletak pada persoalan zonasi yang dapat menjadi perdebatan sengit. Sebelumnya, perihal keberadaan kapal tenggelam ini telah tertulis jelas dalam Keppres Nomor 107 Tahun 2000 bahwa pemerintah berhak atas kapal tenggelam asalkan kapal tersebut "telah tenggelam di perairan Indonesia, ZEE, dan Landas Kontinen yang sudah berumur 50 tahun" (Pasal 1). Namun dalam UNCLOS disebutkan bahwa Zona Ekonomi Ekslusif bukanlah wilayah negara yang bersangkutan, namun negara berhak berdaulat atas kekayaan alamnya. Keberadaan cagar budaya bawah air tentu dapat menjadi polemik perihal persoalan kepemilikannya karena secara empirik peninggalan bawah air bukanlah kekayaan maupun sumber daya alam.

Berdasarkan ketentuandariKonvensiHukum LautInternasional(UNCLOS) kawasan laut yang setidaknya Indonesia memiliki kepentingan didalamnya terdiri dari tiga kelompok: kelompok pertama (perairan pedalaman, perairan nusantara, dan laut territorial) adalah wilayah tempat Indonesia melakukan praktik penerapan kedaulatan pada semua sektor. Kewenangan negara pada wilayah ini mencakup 
semua kegiatan di laut atas berbagai kekayaan alam, lingkungan, dan ruang; kelompok kedua adalah wilayah laut dimana Indonesia memiliki hak berdaulat atas kekayaan alam dan kewenangan-kewenangan tertentu. Wilayah laut ini tidak dianggap sebagai bagian dari wilayah wilayah suatu negara. Adapun wilayah laut kelompok dua ini terbagi atas contiguous zone (24 mil dari garis pangkal pantai atau 12 mil dari perairan territorial), ZEE (200 mil dari garis pantai), dan Landas Kontinen (dapat melebihi jarak 200 mil dari garis pantai). Pada kelompok kedua ini pemerintah dapat mengambil tindakan atas pelanggaran hukum dan mengatur wewenang untuk pemeliharaan laut dan pembangunan instalasi tertentu; dan kelompok ketiga adalah wilayah dimana pemerintah suatu negara dapat memiliki kepentingan dan kebebasan berlayar. Kategori dalam kelompok ini adalah laut bebas.

Dalam ketentuan mengenai ZEE dijelaskan bahwa negara memiliki kewenangan atas sumber daya tertentu. Karena adanya ambiguitas atas apa yang dimaksud sebagai kekayaan sumber daya dalam kaitannya dengan peninggalan bersejarah yang tenggelam di dalam air, tentu otoritas yang berwenang perlu segera menetapkan bahwa peninggalan tersebut berada dibawah kewenangan pemerintah Indonesia. Hasyim Djalal menyebutkan hal ini merujuk pada UU Nomor 5 Tahun 1992 yang berfungsi sebagai hukum tentang cagar budaya sebelum UU Nomor 11 Tahun 2010 diberlakukan. Menurut Djalal, kiranya istilah "wilayah Republik Indonesia" dalam UU Nomor 5 Tahun 1992 Pasal 2 Ayat (1) dijelaskan dalam Peraturan Pemerintah Nomor 10 Tahun 1993 adalah "wilayah hukum Republik Indonesia" yang meliputi seluruh yurisdiksi Indonesia (Djalal, 2007). Yang harus diperhatikan pula adalah dalam wilayah landas Kontinen maupun yang diluar itu, pemerintah tidak memiliki kewenangan apapun. Padahal jumlah kapal tenggelam yang tersebar di wilayah tersebut di sekitar perairan Indonesia jumlahnya sangat banyak.

Terkait klaim terhadap kepemilikan cagar budaya bawah air ini, pemerintah Indonesia dapat mengambil keuntungan dalam urusan cagar budaya bawah air di wilayah ZEE dan landas kontinen. Sebagaimana tertulis dalam UU Nomor 11 Tahun 2010 dan Keppres Nomor 19 Tahun 2007, Indonesia hanya menyatakan kepemilikan terhadap peninggalan bawah air di wilayah tersebut tanpa pembahasan lebih lanjut mengenai bagaimana mekanisme perlindungan dan kerjasama dengan negara lain dalam isu perlindungan peninggalan bawah air. Sedangkan konvensi perlindungan cagar budaya bawah air menetapkan berbagai regulasi terkait perlindungan di perairan internal, perairan kepulauan, dan laut teritorial (Pasal 7); di zona tambahan (Pasal 8); ZEE dan landas kontinen (Pasal 10). Dalam aspek zonasi laut, bergabungnya Indonesia dengan rezim dapat memberikan sisi positif bagi wilayah yang sudah disebutkan.

Hanya saja, jika konvensi memberikan aturan jelas mengenai persoalan zonasi, justru permasalahan ini menimbulkan ambiguitas antara konvensi perlindungan cagar budaya bawah air dengan UNCLOS. Itu tandanya sesuai ketentuan yang ada mengenai zona ekonomi ekslusif, negara hanya berhak terhadap sumber daya alamnya saja. Menurut pengamatan penulis, artikelartikel dalam konvensi 2001 sifatnya cenderung normatif dan kebanyakan urusan koordinasi antar negara bergantung kepada komunikasi antar negara yang terlibat itu saja. Jika asumsi tersebut benar adanya, maka mungkin saja keputusan Indonesia yang belum bergabung diakibatkan adanya ketidakcocokan persoalan zonasi dapat terbaca. Dalam manual guide yang dapat diunduh pada website resmi konvensi disebutkan bahwa UNESCO tidak terlibat dalam sengketa antar negara, 
lalu dalam beragam artikel konvensi disebutkan bahwa setiap negara saling berkoordinasi antar pihak yang terlibat secara mandiri. Keduanya menyebabkan efektifitas fungsi dari rezim perlindungan cagar budaya bawah air menjadi dipertanyakan.

\section{Persoalan Kedaulatan}

Dalam Konvensi UNESCO tahun 2001 tentang Perlindungan Cagar Budaya Bawah air disebutkan bahwa setiap negara memiliki hak eksklusif untuk mengatur dan mengizinkan kegiatan-kegiatan yang berkaitan dengan cagar budaya bawah air dalam perairan yang terbatas di perairan kepulauan saja (Pasal 7) (UNESCO, 2001). Maka dari itu kewenangan suatu negara hanya berlaku di wilayah laut kelompok pertama saja (perairan nusantara, laut territorial). Hal ini tentu dapat mengurangi potensi kepemilikan Indonesia terhadap banyak peninggalan berharga di bawah laut kelompok kedua dan ketiga yang Indonesia pun memiliki kepentingan atasnya. Disamping itu, konvensi ini juga memberlakukan aturan bagi negara yang berkepentingan terhadap peninggalan cagar bawah air di contiguous zone untuk menerapkan metode kooperatif. Intinya negara-negara yang terlibat dalam kegiatan seperti pelestarian dan perlindungan harus saling bekerja sama satu sama lain.

Dalam prosesnya, negara yang wilayah lautnya lebih terjangkau dengan cagar budaya bawah air itu disebut sebagai negara pihak dan bertindak sebagai koordinator. Negara koordinator memiliki wewenang untuk mengatur dan memberi izin bagi beragam kegiatan yang berkaitan dengan cagar budaya bawah air di zona tambahannya (contiguous zone-nya) disamping memiliki wewenang khusus, negara koordinator wajib menginformasikan temuannya ke negara sekitarnya dan ke partisipan dari konvensi untuk melakukan penindakan bersama (Pasal 8). Frase 'penindakan bersama' ini memiliki pengertian yang diartikan berbeda oleh sejumlah kalangan, apalagi bagi para pembuat kebijakan negara. Karena penekanan itu, maka secara implisit Konvensi UNESCO tahun 2001 memberlakukan aturan bahwa negara pantai atau pesisir tidak mempunyai hakhak ekslusif untuk memelihara, mengelola, ataupun memanfaatkan benda-benda berharga yang ditemukan di Zona Ekonomi Eksklusif dan landas kontinennya (Djalal, 2007: 39). Terlebih lagi, konvensi 2001 melarang peninggalan bawah air sebagai objek yang memiliki nilai ekonomi. Meskipun pelarangan hal-hal yang berkaitan dengan jual beli cagar budaya telah berlaku dalam UU Nomor 11 Tahun 2010, beberapa regulasi lain seperti Keppres Nomor 25 Tahun 1992, PP Nomor 2 Tahun 2000, Keppres Nomor 107 Tahun 2000, Kepmen KP Nomor 3 Tahun 2000 dan Nomor 39 Tahun 2000 masih memberlakukan kemungkinan bagi peninggalan bawah air untuk digunakan dalam konteks ekonomi.

Berkaitan dengan pemanfaatan untuk kepentingan ekonomi tentu mengembalikan wacana ini ke faktor yang pertama. Karena Indonesia masih berjuang untuk mengambil kebijakan yang tepat tentang masa depan peninggalan bawah air yang tenggelam di wilayah lautnya. Kebingungan menentukan arah itu bisa disebakan karena memanfaatkan peninggalan bawah air untuk kepentingan ekonomi secara probabilitas juga memungkinkan pemerintah untuk menerima dampak positifnya. Tentu saja dengan catatan bahwa urusan konservasi harus lebih diutamakan sebelum pemanfaatan secara ekonomi ini diterapkan. Perbedaan prinsip terhadap arah prioritas perlindungan cagar bawah air Ini menunjukan bahwa Indonesia belum memiliki kesiapan untuk meratifikasi Konvensi Perlindungan Cagar Budaya Bawah air UNESCO tahun 2001. 
Perbedaan prinsip antara UU domestik dengan regulasi konvensi juga dapat menjadi pertaruhan bagi pemerintah Indonesia untuk mengambil keputusan apakah perlu meratifikasi konvensi tahun 2001 atau tidak (Widiati, 2018). Secara langsung adanya perbedaan prinsip memiliki relasi erat dengan faktor yang ketiga, yaitu faktor kedaulatan. Karena negara koordinator tidak memiliki hak ekslusif atas peninggalan bawah air yang ada di ZEE dan landas kontinen. Pasal 7 dalam konvensi disebutkan bahwa negara pantai memiliki hak untuk mengaplikasikan kedaulatannya di wilayah perairan internal, kepulauan, hingga territorial. maka Indonesia berpotensi mengalami kerugian apabila peninggalan bawah air yang masif itu dikelola oleh rezim. Faktor kedaulatan menjadi signifikan manakala penindakan yang didasari atas asas kerja-sama (penindakan bersama) berisiko membebaskan negara-negara partisipan rezim untuk secara bebas memasuki teritori laut Indonesia. Jika ini terjadi maka harus ada kalkulasi maupun perhitungan bahwa pihak asing itu dapat mengeksploitasi kekayaan historis sejarah bawah laut milik negara dengan memasuki wilayah laut yang yurisdiksinya masih berada di dalam kewenangan pemerintah Indonesia. Dalam Pasal 9 dijabarkan apabila skema kerja sama perlindungan bagi cagar budaya bawah air melibatkan reporting and notification. Dalam paragraf 4 pasal tersebut tertulis Direktur Jenderal UNESCO akan menginformasikan segala informasi yang ditujukan kepadanya bagi semua negara anggota apabila ada aktifitas yang akan dilakukan terhadap suatu cagar bawah air. Paragraf 4 merupakan kelanjutan dari paragraf 3 yang menekankan bahwa negara anggota harus melapor kepada Direktur Jenderal jika mendapati temuan ataupun aktifitas yang ditujukan kepada cagar bawah air. Penginformasian ini kepada berbagai pihak yang 'merasa berkepentingan' dapat berpotensi melanggar kedaulatan nasional jika konvensi akhirnya memutuskan untuk diadakan penindakan bersama di situs atau kawasan cagar budaya yang dimaksud.

Meskipun dalam Pasal 10 disebutkan bahwa negara anggota yang zona ekonomi eksklusif atau landas kontinennya terdapat peninggalan bawah air memiliki hak untuk melarang atau memberi izin kepada pihak asing sesuai UNCLOS, namun negara tersebut harus bertindak sesuai dengan mufakat keputusan dari para peserta konvensi (paragraf 6) dan kolaborasi dengan negara pemilik dari bendera asal kapal tersebut jika peninggalan bawah airnya itu berupa kapal (paragraf 7). Hal ini tentu berdampak pada pemerintah Indonesia akan kehilangan haknya (baik itu besar maupun kecil) terhadap kepentingan nasionalnya sendiri. Dengan melibatkan pihak-pihak asing dalam melakukan ekplorasi, eksploitasi, maupun kegiatan lain yang ditujukan kepada peninggalan bawah air, maka dikhawatirkan pihak asing itu dapat berpotensi merugikan kepentingan nasional dalam perlindungan cagar budaya bawah air. Skema kerja sama yang dibangun dalam konvensi dapat disalah gunakan sebagai kesempatan bagi pihak asing untuk memasuki wilayah negara dengan legitimasi yang berasal dari rezim yang bersangkutan. Bahkan meskipun rezim ini tidak diikuti oleh negara-negara besar, namun ketentuan seperti yang tertulis pada paragraf 7 pasal 10 dapat dijadikan kunci bagi negara besar eks-kekuatan kolonial (yang notabene kapal-kapal perangnya berserakan di dasar laut nusantara) untuk intervensi di wilayah laut negara dengan dalih kolaborasi (Widiati, 2018). 


\section{Kesimpulan}

Dari ketiga faktor tersebut, penolakan Indonesia terhadap konvensi disebabkan karena kapabilitas sumber daya manusia dan infrastruktur untuk menciptakan kerja sama yang optimal belum terwujud. Kapabilitas itu tidak tampak karena memang pemerintah tidak memprioritaskan perangkat hukum negara untuk diintegrasikan dengan hukum internasional. Menurut Sitarman, penolakan negara dalam satu kerja sama internasional dapat disebabkan adanya tekanan secara domestik maupun internasional. Sedangkan Konvensi 2001 tentang perlindungan cagar bawah air merupakan sebuah kerja sama yang bahkan tidak diratifikasi negara-negara adidaya. Karena tidak adanya negara adidaya itulah tekanan internasional agar Indonesia mau meratifikasi pun minim. Sehingga apabila Indonesia merasa konvensi 2001 tidak dapat memberikan dampak positif, negara berhak menolaknya.

Dalam paradigma realisme, negara sejatinya dapat merasa tidak yakin terhadap intensi apapun dari negara-negara lain (Mearsheimer, 1994). Sehingga secara hubungan internasional, kebijakan menolak ratifikasi merupakan upaya dari pemerintah untuk bertahan (survive) dari ketidakpastian. Ketidakpastian itu muncul jika dilihat dari partisipan konvensi yang bukan kekuatan maritim adidaya. Apalagi sejak awal Portugal dan Spanyol adalah negara yang paling alot bernegosiasi soal pembentukan konvensi (keduanya adalah eks-kolonial Indonesia). Peran aktor-aktor negara dalam tesis ini terjalin dalam tatanan diskursus dan rezim cagar bawah air dapat dipersepsikan sebagai distributor power bagi pihak-pihak yang berkepentingan terhadap kedaulatan negara Indonesia. Karena dalam asumsi realis tujuan negara adalah survival, maka relasi power antara rezim dengan negara dalam kasus ini berkaitan dengan hak dan persepsi penyalahgunaan kesepakatan. Jika negara berani mempertaruhkan legalitas dalam mengelola wilayah lautnya maka opsi ratifikasilah yang akan diambil.

Institusi menerapkan aturan untuk ekstensifikasi norma yang dianutnya sedangkan pemerintah menghalau potensi kerugian akibat ratifikasi tersebut. Perjanjian multilateral membutuhkan adanya penandatanganan kontrak oleh negara agar bisa secara formal dianggap berpartisipasi dalam perjanjian tersebut. Dari berbagai data yang sudah dikumpulkan, kecenderungan rezim perlindungan cagar budaya bawah air berdasarkan isi konvensinya belum bisa memberikan manfaat secara nasional bagi Indonesia. Oleh karena itu, partisipasi Indonesia dalam perlindungan cagar budaya bawah air hanya sebatas penandatanganan kerja sama tanpa melibatkan ratifikasi. Penolakan untuk melakukan ratifikasi adalah pilihan paling realistis bagi pemerintah Indonesia karena dengan begitu pemerintah merasa tidak perlu khawatir hukum dan regulasinya terintegrasi dengan ketentuan-ketentuan konvensi yang dinilai bisa mengganggu kedaulatan negara.

Perilaku sebuah negara dapat menerima atau menolak ratifikasi sebuah ratifikasi asalkan mampu menanggung biaya konsekuensi jika memilih salah satunya. Dalam Pasal 2 dan Pasal 9 disebutkan bahwa konvensi ini menekankan aspek kerja sama dan saling koordinasi antar negara terhadap klaim cagar budaya bawah air. Pemerintah mengakui saat ini tengah menyusun berbagai naskahnaskah akademis perihal aturan konvensi apakah dapat memberikan manfaat bagi pemerintah. Saat ini pemerintah beranggapan jika ikut berpartisipasi dalam konvensi maka Indonesia beresiko kehilangan potensi peninggalan bawah airnya yang hampir semuanya merupakan relik dan identitas yang dimiliki oleh bangsa lain (Widiati, 2018). Kerugian tentu tidak dapat dihindari jika argumen ini 
dijadikan acuan mengingat negara Indonesia terbentuk dari sejarah yang panjang akan pertemuan berbagai bangsa yang meninggalkan legacy kebudayaannya di wilayah perairan nusantara. Apabila dalam proses koordinasi terjadi sengketa antara pemerintah Indonesia dengan negara lain yang mengklaim sebuah peninggalan bawah air maka itu akan sangat menguras waktu dan Indonesia tidak akan memiliki kesempatan untuk meningkatkan posisinya sebagai negara maritim terbesar di dunia. Meskipun begitu konvensi ini bukan berarti tanpa hal positif yang manfaatnya bisa diraih oleh pemerintah Indonesia. Hukum yang berlaku di Indonesia tentang cagar budaya hingga pemanfaatan kapal tenggelam tidak menyebutkan bagaimana mekanisme perlindungan cagar yang terletak selain di dalam perairan internal negara. Konvensi UNESCO tahun 2001 jelas menyebutkan dalam Pasal 8, Pasal 10, Pasal 11 dan Pasal 12 bahwa konvensi ini mengatur perihal perlindungan cagar budaya bawah air pada zona ekonomi ekslusif, zona tambahan, dan landas kontinen. Ini tentu dapat dimanfaatkan oleh pmerintah untuk melakukan riset hingga pemanfaatan terhadap peninggalan bawah air di area-area tersebut.

Pada akhirnya, perilaku negara dalam meratifikasi sebuah perjanjian multilateral tercermin saat mengikuti rasional yang ada bahwa sistem internasional itu sejatinya bersifat self-help. Jika ranah internasional identik dengan power and accomodation seperti yang dibayangkan oleh Waltz (1979), maka politik domestik yang antara lain adalah ranah wewenang, administrasi, dan hukum akan melebur ke dalam tatanan itu melalui sebuah rezim. Dalam sebuah kerangka partisipasi negara, sebuah rezim dapat menjelma sebagai unit revisionis yang menarik sebagian kecil (atau besar) wewenang yang dimiliki negara terhadap diskursus tertentu. Sentralisasi instrumen hukum domestik dengan internasional tentu memiliki konsekuensi berupa adanya penambahan sekaligus pengurangan aspek-aspek tertentu sesuai dengan perjanjjian yang ada. Dari sini indikasi bahwa pemerintah Indonesia mengedepankan rasional terlihat secara eksplisit. Pertimbangan pemerintah untuk menunda proses ratifikasi konvensi tahun 2001 didasari pada kekhawatiran peninggalan bawah air di perairan nusantara menjadi tidak aman karena dapat diklaim oleh bangsa lain, sistem kerja sama yang ada juga dianggap berpotensi mengganggu kedaulatan wilayah perariran karena berarti negara membiarkan pihak asing untuk menyelam dan melakukan aktifitas di laut negara.

\section{Daftar pustaka}

Axelrod, R., \& Keohane, R. O. (1985). Achieving Cooperation under Anarchy: Strategies and Institutions. World Politics, 38(1), pp. 226-254.

Batubara, A. M. (2014). Perlindungan Cagar Budaya Bawah Air dalam Kajian Analisis Hukum. Balai Konservasi Borobudur, 8(1), pp. 48-57.

Botcheva, L., \& Martin, L. L. (2001). Institutional Effects on State Behavior: Convergence and Divergence. International Studies Quarterly, 45(1), pp. 1-26.

Campbell, P. (2005). Indonesian Archipelagic Sea Lanes. Dalam: Papers in Australian Maritime Affairs No. 16: Australian Maritime Issues 2005. Canberra: Commonwealth of Australia.

Chayes, A., \& Chayes, A.H. (1995) The New Sovereignty: Compliance with International Regulatory Agreements. Cambridge, MA: Harvard University Press.

Djalal, H. (2007). Peninggalan Bawah Air dan Kaitannya Dengan Hukum Kelautan. Makalah disajikan dalam Pertemuan Konsultatif Tingkat Nasional tentang 
Warisan Budaya Bawah Air, Bogor, 12-14 Juni, Direktorat Jenderal Sejarah dan Purbakala, Departemen Kebudayaan dan Pariwisata.

Frieden, J. A., Lake, D. A., \& Schultz, K. A. (2009). World Politics: Interests, Interactions, Institutions. New York: Norton.

Grieco, J. (1988). Anarchy and the Limits of Cooperation: A Realist Critique of the Newest Liberal Institutionalism. International Organization, 42(3), pp. 285-507.

ICOMOS (1996). The ICOMOS Charter on the Protection and Management of Underwater Cultural Heritage. Available at: https://www.icomos. org/en/faq-doccen/179-articles-en-francais/ressources/charters-andstandards/161-charter-on-the-protection-and-management-of-underwatercultural-heritage\#: : text=Charter $\% 20$ on $\% 20$ the $\% 20$ Protection $\% 20$ and $\% 20$ Management $\% 20$ of $\% 20$ Underwater $\% 20$ Cultural $\% 20$ Heritage,Print\&text=This $\% 20$ Charter $\% 20$ is $\% 20$ intended $\% 20$ to, and $\% 20$ in $\% 20$ the $\% 20$ deep\%20oceans. (Accessed 13 April 2020).

Keliat, M. (2005). Negara, Globalisasi, dan Intelijen. Dalam: A. Widjajanto (ed.), Reformasi Intelijen Negara. Jakarta: Pacivis UI dan Friedrich Elbert Stiftung.

Keohane, R. O., \& Martin, L. L. (1995). The Promise of Institutionalist Theory. International Security, 20(1), pp. 39-51.

Laksmana, E. (2011). The Enduring Strategic Trinity: Explaining Indonesia's Geopolitical Architecture. Journal of the Indian Ocean Region, 7(1), pp. 95-116.

Manders, M. (2012). Training Manual for the UNESCO Foundation Course on the Protection and Management of Underwater Cultural Heritage in Asia and the Pacific,. In Situ Preservation (pp. 210-245). Bangkok: UNESCO.

Mearsheimer, J. J. (1994). The False Promise of International Institutions. International Security, 19(3), pp. 5-49.

Mintz, A., \& DeRouen Jr., K. (2010). Understanding Foreign Policy Decision Making. Cambridge: Cambridge University Press.

Ridwan, N. N. (2014). Maritime archaeological exploration in Indonesian waters. Shipwrecks around the world: Revelations of the Past pp. 425-449. New Delhi: Delta Book World.

Sitaraman, S. (2009). State Participation in International Treaty Regimes. Surrey: Ashgate Publishing Limited.

Snidal, D. (1991). Relative Gains and the Pattern of International Cooperation. American Political Science Review, 85(3), pp. 701-726.

Tanudirjo, D. A. (2007, April 20). Cultural Landscape Heritage Management in Indonesia. First International Symposium on Borobudur Cultural Landscape . Jogjakarta, Indonesia: Center for Heritage Conservation.

Tismananda, K. M. (2016). Designation of The Strategic Sea Lanes According to UNCLOS 1982. International Journal of Business, Economics and Law, 10(4).

UN General Assembly (1982). United Nations Convention on the Law of the Sea. Available at: https://www.un.org/depts/los/convention_agreements/texts/ unclos/unclos_e.pdf (Accessed 13 April 2020).

UNESCO (2001). Convention on the Protection of the Underwater Cultural Heritage. Available at: https://unesdoc.unesco.org/ark:/48223/pf0000126065 (Accessed 13 April 2020).

Viotti, P. R., \& Kauppi, M. V. (2012). International Relations Theory. Glenview: Pearson Education.

Waltz, K. (1979). Theory of International Politics. Reading, MA: Addison-Wesley.

Widiati, R. (2018, Mei 14). Indonesia tidak berencana bergabung dengan Konvensi UNESCO tahun 2001 tentang Perlindungan Cagar Budaya Bawah Air (wawancara). 